\title{
THE IMPACT OF AN IN-SERVICE TRAINING PROGRAM ON THE SELF-EFFICACY OF SPECIAL AND GENERAL EDUCATION TEACHERS
}

\author{
Sotiria Tzivinikou \\ University of Thessaly, Volos, Greece \\ E-mail: sotitzivi@uth.gr
}

\begin{abstract}
Teachers 'professional development is the key to education improvement. On that basis, the present study aimed to investigate the impact of a 6-month in-service training program in the context of the continuing professional development for educators on educational practice. The main objective of the training program was to improve the educators' teaching skills, to enrich their practices with the most effective strategies and with the newest findings from research evidence in order to increase the quality of their educational interventions for students with special educational needs. An innovation of that program was the simultaneous training of both general and special education teachers in pairs, smoothing the dividing lines between general and special education in their daily instructional practice. The participants were 30 educators, divided into 15 pairs. Each pair was working in the same inclusive school sharing the responsibility of the educational support of a student with learning problems. The estimation of the impact of the program was investigated by measuring the educators' increasing sense of self-efficacy in relation to their instructional skills and overall effectiveness of their educational interventions for their students with learning difficulties. A pre and post evaluation research design was employed and the findings showed that the training program had a positive impact on the educators'self-efficacy and their effectiveness regarding collaborative educational interventions for their students.
\end{abstract}

Key words: continuing professional development, in-service training, self-efficacy.

\section{Introduction}

Over the past few decades, teaching in Greece was considered to be an art and not a science. So, it was acceptable for teachers, after receiving their degrees, to not pursue further training in pedagogy and didactics. Therefore, the attempt to create official structures for in-service teacher-training has started very recently, particularly, in the middle of ' 00 s. More specifically, the official efforts for in-service training for teachers culminated in 2011, with the proposed reform of the Education Minister A. Diamantopoulou, entitled «The New School-Students Come First». However, the reform momentum was weakened due to the economic crisis, and school advisors were appointed to carry out the reform project, without the provision of substantial financial and scientific support but relying merely on their own, very limited resources. The school advisors are still making continuous efforts to cope with teacher training requirements, as they are aware of the significance of the in-service training in updating the practicing teachers and special educators' knowledge and skills so as to be congruent with the current best practices (Horrocks, 2010). It is argued that teachers in inclusive settings may never acquire the requisite skills for successful teacher collaboration, unless it becomes the main element of effective practices in inclusive education (Sledge \& Pazey, 2013).

Both general and special education teachers have separate training opportunities and they very often struggle to develop instructional skills needed to deal with their teaching-related 
Sotiria TZIVINIKOU. The impact of an in-service training program on the self-efficacy of special and general education teachers

PROBLEMS

OF EDUCATION

IN THE $21^{\text {st }}$ CENTURY Volume 64, 2015

goals in inclusive settings, where effective collaboration between special education teachers and other educational stuff is one of the main components that characterize effective educational interventions for teaching disabled students.

\section{Problem of Research}

Educational research in Greece was and continues to be low funded, regardless of the present financial crisis. So, it is of small scale, weak and without major impact on the education policy that usually stems from partisan positions and perceptions and not from research findings. Similarly, the in-service training of teachers is not based on research. Although, some notable efforts for teachers' training were developed, they were not systematic and researchbased. The present study as a part of a larger investigation attempted to fill gaps and help planning training activities, based on research. It has been reported as an in-service training for primary teachers and special educators aiming to promote their collaboration in order to improve the quality of their teaching and the implementation of educational interventions for students with mild special needs and learning disabilities in inclusive schools.

\section{Research Focus}

Researchers have recommended several effective teacher training techniques for general education teachers and those who work with students with learning disabilities. The terms: "Lifelong learning" and "in-service training" are used interchangeably to refer to teachers" professional development as well as the attempt for continuous improvement of the offered educational services. Recently, "continuing professional development" has been the most widely used term for on-going education and training for the professions (Bobb, \& Earley, 2007; Knight, 2007), that has also been adopted by the European Network Eurydice (available at http://eacea. ec.europa.eu/education/eurydice/). In the OECD (Organization for Economic Co-operation and Development) study, it is argued that the concept of "professional development" is broader than the concept of "training" and more suitable for expressing new attitudes concerning educational institutions as "learning organizations" (OECD, 1998).

Professional development of educators accomplished through constant scientific and vocational support, constitutes the basic element for improving the provided educational services, by trying to overcome, on the one hand, the deficiencies and weaknesses of educators' undergraduate education and, by following, on the other hand, the evidence derived from continuing development of educational research. The effectiveness of the training program is correlated with the necessary investigation and finally satisfaction of educators' learning needs, as they perceive them (Kokkos, 1999). In addition, the training program's effectiveness is related to the adoption of approaches and practices that are suitable for adult education.

The terms "adult education" and "andragogy", according to Malcolm Knowles, are defined as the art and science of helping adults to learn (Knowles, 1984) by taking into account their cognitive characteristics and involving them actively into the educational process, so that learning can be based on their personal experiences. Jarvis, (1985) has characterized Knowles as an innovator and has highlighted the differences between pedagogy and andragogy and has summarized their main assumptions (see table 1). 
Table 1. A comparison of the assumptions of pedagogy and andragogy following Knowles (Jarvis 1985, pp. 51).

\begin{tabular}{lll}
\hline & Pedagogy & Andragogy \\
\hline The learner & $\begin{array}{l}\text { Dependent. Teacher directs what, when, how } \\
\text { a subject is learned and tests that it has been } \\
\text { learned }\end{array}$ & $\begin{array}{l}\text { Moves towards independence } \\
\text { Self-directing. Teacher encourages and nurtures } \\
\text { this movement }\end{array}$ \\
\hline $\begin{array}{l}\text { The learner's } \\
\text { experience }\end{array}$ & $\begin{array}{l}\text { Of little worth. Hence teaching methods are } \\
\text { didactic }\end{array}$ & $\begin{array}{l}\text { A rich resource for learning. Hence teaching meth- } \\
\text { ods include discussion, problem-solving, etc. }\end{array}$ \\
\hline $\begin{array}{l}\text { Readiness to } \\
\text { learn }\end{array}$ & $\begin{array}{l}\text { People learn what society expects them to, so } \\
\text { that the curriculum is standardized }\end{array}$ & $\begin{array}{l}\text { People learn what they need to know, so that learn- } \\
\text { ing programs are organized around life application }\end{array}$ \\
\hline $\begin{array}{l}\text { Orientation to } \\
\text { learning }\end{array}$ & $\begin{array}{l}\text { Acquisition of subject matter. Curriculum } \\
\text { organized by subjects. }\end{array}$ & $\begin{array}{l}\text { Learning experience should be based on experi- } \\
\text { ences, since people are performance centered in } \\
\text { their learning }\end{array}$ \\
\hline
\end{tabular}

Effective in-service training leads to enriched learning school environments (Rosenholtz, 1991) that will constitute communities that will allow learning and constant development to both students and educators, who work there and have a common vision and belief in lifelong learning.

Recent studies concerning educators' training suggest the method of coaching as an effective educator training method. According to this method, the instructional coach helps the trainees-educators to incorporate research-based instructional practices and best educational techniques into their teaching practices (Knight, 2007). The instructional coach has to be familiar with a large number of scientifically proven instructional practices for classroom management, content enhancement, specific teaching practices and formative assessment.

Instructional coaching (Knight, 2009) is based on equality between coaches and teachers, choice, i.e. teachers' ability to choose what and how to learn, voice, i.e. encouraging teachers to have their personal opinion, discussion and reflexivity, praxis/implementation, i.e. the ability to immediately put into practice the newly gained knowledge in the classroom context and reciprocity between the trainer and the trainee.

Effective training can increase teachers' efficacy as well as their sense of self-efficacy. Bandura, (1997), stated that self-efficacy is a person's belief in his or her ability to succeed in a particular situation. Self-efficacy beliefs contribute to motivation in several ways and enable people to perform and manage potentially difficult situations (Pajares, 1996). People's beliefs about their efficacy provide the foundation for human motivation, well-being and personal fulfilment. Self-efficacy affects teaching practices and teacher effectiveness, which is associated with the learning outcomes as well as student motivation and self-efficacy (Henson et al., 2001; Tschannen-Moran \& Hoy, 2007; Caprara et al., 2006). Teachers with high self-efficacy have good organizational skills and they are dedicated to teaching (Tschannen-Moran \& Hoy, 2001). Several studies have shown that high self-efficacy is generally linked to strong motivation for teaching and successful classroom management (Raudenbush, Rowan \& Cheong, 1992).

Teacher efficacy refers to a judgment of his or her capacities and their influence on students' learning. This judgment has powerful effects on both students' learning and their behavior in the classroom (Woolfolk et al., 2008). Research findings indicate that efficacy affects the effort teachers invest in teaching, the goals they set and their capacities for planning and organization (Tschannen-Moran and Hoy, 2001). Teachers with high sense of self efficacy tend to be more open to new ideas and teaching methods and strive to meet the needs of their students, including those with diverse capacities.

Teacher self-evaluation is considered to be an essential tool for improving the design and planning process, helping to identify strengths and areas for development. The achievement of learning goals, teaching planning, the use of appropriate teaching material and instructional 
Sotiria TZIVINIKOU. The impact of an in-service training program on the self-efficacy of special and general education teachers

PROBLEMS

OF EDUCATION

IN THE $21^{\text {st }}$ CENTURY

Volume 64, 2015

methods, the effective time management, the creation of a positive learning environment, the effective student assessment process by using the proven tools and moreover, the identification of the students' educational needs and the actual learning outcomes as well as constructive feedback are only some of the significant factors that characterize effective teaching (Kyriakides, Creemers \& Antoniou, 2009).

The present study presents a 6-month in-service training program, as part of a broader program that has combined in-service training and the coaching format, entitled as "General and special education bridging - Promoting Inclusion" that was realized in Greece (henceforth referred to as 'program'). The study focuses on the in-service training and investigates its impact on the self-efficacy of the participants which constitutes an important element that influences the quality of teaching and educational interventions for students with learning disabilities. The study's research question was about the impact of the in-service training program on general and special teachers' sense of self-efficacy, as an essential factor of effective teaching.

\section{Methodology of Research}

\section{General Background of Research}

The program has been designed according to the educational cycle proposed by Bobb and Earley (2007) including six stages, i) identification of the Training and Development (T\&D) needs, ii) analysis of the T\&D, iii) planning and designing of T\&D, iv) implementation of T\&D, v) monitoring of $T \& D$, and finally vi) evaluation of $T \& D$ and its impact (figure 1 ).

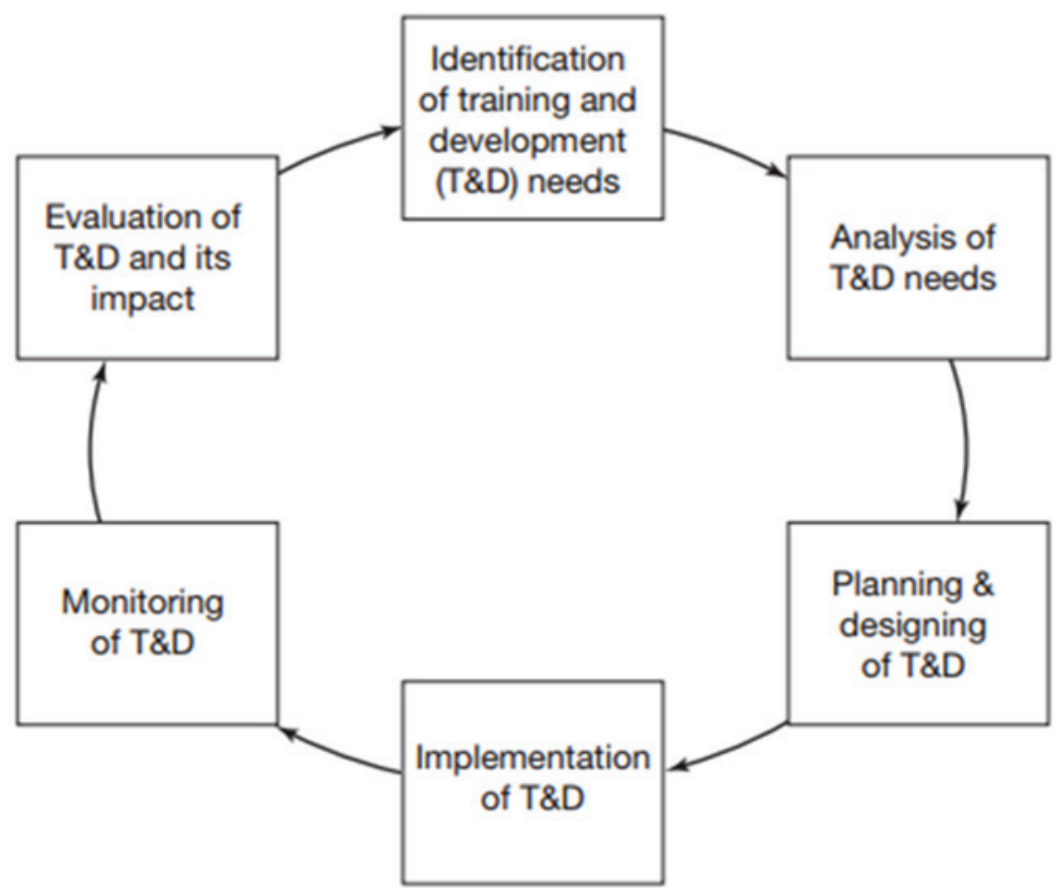

\section{Figure 1: The Training and Development Cycle from Sara Bobb \& Peter Earley, (Bobb \& Earley, 2007, pp. 33).}

The total in-service program was followed all of the six cycle stages, three of them described in the present article i.e. implementation of the training and development program, monitoring of the program and evaluation of the program, while the other three stages are de- 
scribed in a separate article (Tzivinikou, in press). The research took place in Thessaloniki, the second largest city in Greece, and it lasted six months.

\section{Sample of Research}

The research participants were 30 general and special teachers of primary education, who fulfilled the terms of the program's call. Among the participants, three of them were men, whereas 27 were women. Their average professional experience was about 10 years, ranging from one to ten years. The majority of them, mainly special educators, had some experience concerning participation in training programs and similar match-days, conferences and educational meetings.

\section{Procedure}

The main characteristic of the present program was the simultaneous participation of both general and special educators working together sharing the responsibility of the educational support of a student with learning problems, in their inclusive school.

The program was divided into two phases, the first one included 30-hour lectures on theoretical topics about the design and implementation of best practices and effective interventions for students with various problems and disorders, such as learning disabilities, autism, behavior problems and mild mental retardation, as well as the impact of collaboration of educational stuff on the effectiveness of these interventions. The second phase included a 70-hour practicum, during 10 weeks. More specifically, each pair of educators was expected to collaborate in order to design and implement an intervention program for a student with learning difficulties that attended their school. During this procedure, the teachers were provided with consistent supervision/monitoring, support and feedback by the scientific coordinators of the training program using the method of coaching (Knight, 2007, 2009).

The first 30-hour phase consisted of 3-hour lectures per week for 10 weeks. At the end of each program, the trainers and trainees discussed and reflected on the program's content; whether it met the instructional needs, generally, i.e. whether the objectives of the program converged to the overall objectives of the program. Thereafter, some changes were made according to this reflection. Generally, only a few changes were made, mainly referring to technical issues, such as the specific day and hours of the program etc. Similarly, but on an individual basis, in the second phase, the reflection procedure was realized every week during the practicum/each week practicum and used as feedback for changes and improving of the practicum itself.

The impact of the training-program was estimated in two ways, on the one hand, the participants filled in an open-ended questionnaire, expressing their beliefs about the design and implementation of the program and how it influenced their basic teaching skills such as lesson planning, teaching methods and strategies used by them. On the other hand, the participants filled in the TSES 24-item checklist (Tschannen-Moran \& Woolfolk Hoy, 2001) estimating their sense of self-efficacy before the training and after that, following the pre- and post-test design (Cohen, Manion, Morrison, 2011).

\section{Instrument}

Firstly, an instrument from literature was used for data collection. Initially, teacher efficacy was measured with the TSES 24-item long form (translated in Greek), (Tschannen-Moran \& Woolfolk Hoy, 2001). All of these items were grouped into the three subscales ( 8 items for each scale), a) Efficacy for student engagement (SE) (8 items), b) efficacy for instructional strategies (IS) (8 items), and c) efficacy for classroom management (CM) (8 items). Participants responded to each of the question using a rating scale, ranging from 1 (nothing) to 9 (a great deal). 
Sotiria TZIVINIKOU. The impact of an in-service training program on the self-efficacy of special and general education teachers

PROBLEMS

OF EDUCATION

IN THE $21^{\text {st }}$ CENTURY

Volume 64, 2015

100

Secondly, a questionnaire with ten open-ended questions was completed by the participants. The questions referred to lesson planning, teaching methods, cooperation between general and special teachers, students' assessment, strategies and sensitization of the school community.

\section{Data Analysis}

Descriptive statistics were used for data analysis; especially paired-sample t-test was used as the most appropriate analysis, for pre-post training data and independent t-test analyzing the means between general and special teachers. Non-parametric independent test was used in order to be identified the influence of the factor of subgroups of teachers, "general and special teachers". And also, the internal consistency was evaluated via the Crombach's alpha coefficient. The second questionnaire was qualitatively analyzed.

\section{Results of Research}

Descriptive statistics and paired samples t-test for TSES 24-item are displayed in table 2. Due to the means of the two phases (pre and post training) and the direction of the $t$-values, it can be concluded that there were statistically significant improvements in the self-efficacy for both, general and special teachers. 
Table 2. Summary of the paired-sample t-test.

\begin{tabular}{|c|c|c|c|c|c|c|c|}
\hline \multicolumn{8}{|c|}{ Descriptive Statistics \& Paired Samples T- Test } \\
\hline \multirow[b]{2}{*}{ TSES 24-item } & \multicolumn{2}{|c|}{ Pre-test } & \multicolumn{2}{|c|}{ Post-test } & \multirow{2}{*}{$\begin{array}{l}95 \% \mathrm{Cl} \\
\text { for mean } \\
\text { Difference }\end{array}$} & \multirow[b]{2}{*}{$\mathbf{t}$} & \multirow[b]{2}{*}{ df } \\
\hline & Mean & SD & Mean & SD & & & \\
\hline $\begin{array}{l}\text { How much can you do to get through to the most } \\
\text { difficult students }\end{array}$ & 1,53 & .507 & 7,13 & 1.737 & $-6,388$ & $-4,812^{*}$ & 29 \\
\hline $\begin{array}{l}\text { How much can you do to help your students } \\
\text { think critically }\end{array}$ & 1,63 & .490 & 6,90 & 1.423 & $-5,924$ & $-4,609^{*}$ & 29 \\
\hline $\begin{array}{l}\text { How much can you do to control disruptive } \\
\text { behavior in the classroom }\end{array}$ & 1,63 & .490 & 7,40 & .814 & $-6,202$ & $-5,332^{*}$ & 29 \\
\hline $\begin{array}{l}\text { How much can you do to motivate students who } \\
\text { show low interest in school work }\end{array}$ & 4,57 & .774 & 7,80 & 1.186 & $-3,777$ & $-2,690^{*}$ & 29 \\
\hline $\begin{array}{l}\text { To what extent can you make your expectations } \\
\text { clear about student behavior }\end{array}$ & 4,47 & .900 & 7,67 & 1.269 & $-3,823$ & $-2,577^{\star}$ & 29 \\
\hline $\begin{array}{l}\text { How much can you do to get students to believe } \\
\text { they can do well in school work }\end{array}$ & 4,33 & .959 & 7,87 & 1.106 & $-4,031$ & $-3,036^{*}$ & 29 \\
\hline $\begin{array}{l}\text { How well can you respond to difficult questions } \\
\text { from your students }\end{array}$ & 4,53 & .860 & 7,80 & 1.157 & $-3,846$ & $-2,687^{*}$ & 29 \\
\hline $\begin{array}{l}\text { How well can you establish routines to keep } \\
\text { activities running smoothly }\end{array}$ & 4,50 & .938 & 7,87 & 1.432 & $-3,991$ & $-2,743^{*}$ & 29 \\
\hline $\begin{array}{l}\text { How much can you do to help your students } \\
\text { value learning }\end{array}$ & 4,27 & .980 & 6,57 & 2.046 & $-3,085$ & $-1,515^{*}$ & 29 \\
\hline $\begin{array}{l}\text { How much can you gauge student comprehen- } \\
\text { sion of what you have taught }\end{array}$ & 4,40 & .932 & 7,80 & 1.031 & $-3,951$ & $-2,849^{*}$ & 29 \\
\hline $\begin{array}{l}\text { To what extent can you craft good questions for } \\
\text { your students }\end{array}$ & 4,67 & .758 & 7,83 & 1.341 & $-3,686$ & $-2,647^{*}$ & 29 \\
\hline How much can you do to foster student creativity & 4,47 & .900 & 7,53 & 1.137 & $-3,671$ & $-2,463^{*}$ & 29 \\
\hline $\begin{array}{l}\text { How much can you do to get children to follow } \\
\text { classroom rules }\end{array}$ & 4,60 & .932 & 7,37 & 1.098 & $-3,369$ & $-2,165^{\star}$ & 29 \\
\hline $\begin{array}{l}\text { How much can you do to improve the under- } \\
\text { standing of a student who is failing }\end{array}$ & 4,77 & .728 & 7,47 & 1.252 & $-3,192$ & $-2,208^{*}$ & 29 \\
\hline $\begin{array}{l}\text { How much can you do to calm a student who is } \\
\text { disruptive or noisy }\end{array}$ & 4,60 & .814 & 7,73 & 1.112 & $-3,677$ & $-2,590^{*}$ & 29 \\
\hline $\begin{array}{l}\text { How well can you establish a classroom man- } \\
\text { agement system with each group of students }\end{array}$ & 4,83 & .699 & 7,57 & 1.278 & $-3,270$ & $-2,197^{\star}$ & 29 \\
\hline $\begin{array}{l}\text { How much can you do to adjust your lessons to } \\
\text { the proper level for individual students }\end{array}$ & 4,60 & .814 & 8,00 & 1.287 & $-3,896$ & $-2,904^{*}$ & 29 \\
\hline $\begin{array}{l}\text { How much can you use a variety of assessment } \\
\text { strategies }\end{array}$ & 4,33 & .959 & 7,77 & 1.455 & $-4,059$ & $-2,808^{*}$ & 29 \\
\hline $\begin{array}{l}\text { How well can you keep a few problem students } \\
\text { form ruining an entire lesson }\end{array}$ & 4,27 & .980 & 8,17 & .950 & $-4,374$ & $-3,426^{*}$ & 29 \\
\hline $\begin{array}{l}\text { To what extent can you provide an alterna- } \\
\text { tive explanation/ example when students are } \\
\text { confused }\end{array}$ & 4,27 & .980 & 8,00 & .871 & $-4,223$ & $-3,244^{*}$ & 29 \\
\hline How well can you respond to defiant students & 4,17 & 1.053 & 7,80 & .961 & $-4,217$ & $-3,049$ & 29 \\
\hline $\begin{array}{l}\text { How much can you assist families in helping } \\
\text { their children do well in school }\end{array}$ & 4,33 & .959 & 7,53 & 1.279 & $-3,792$ & $-2,608$ & 29 \\
\hline $\begin{array}{l}\text { How well can you implement alternative strate- } \\
\text { gies in your classroom }\end{array}$ & 4,47 & .900 & 7,67 & 1.269 & $-3,758$ & $-2,642$ & 29 \\
\hline $\begin{array}{l}\text { How well can you provide appropriate chal- } \\
\text { lenges for very capable students }\end{array}$ & 4,00 & 1.017 & 7,73 & 1.230 & $-4,313$ & $-3,154^{*}$ & 29 \\
\hline
\end{tabular}


PROBLEMS

OF EDUCATION

IN THE $21^{\text {st }}$ CENTURY

Volume 64, 2015

102

On the other hand, the identification of differences between two subsamples "general teachers" and "special teachers" was used non-parametric test due to the size of the two subsamples $(<30)($ IBM, 2012). The results in the Table 3 and Figure 2, show that the two independent samples were not statistically significant so the factor of "general or special teacher" did not affect data.

Table 3. Non-parametric, independent samples, "general and special teachers".

\begin{tabular}{lllll}
\hline Null Hypothesis & Test & Sig. & Decision \\
\hline $1 \quad \begin{array}{l}\text { The distribution of PRE_TSES is the same across } \\
\text { categories of General and Special Education Teach- } \\
\text { ers }\end{array}$ & $\begin{array}{l}\text { Independent Samples } \\
\text { Mann-Whitney U Test }\end{array}$ &, $345^{1}$ & $\begin{array}{l}\text { Retain the null } \\
\text { hypothesis. }\end{array}$ \\
\hline 2 & $\begin{array}{l}\text { The distribution of POST_TSES is the same across } \\
\text { categories of General and Special Education Teach- } \\
\text { ers }\end{array}$ & $\begin{array}{l}\text { Independent Samples } \\
\text { Mann-Whitney U Test }\end{array}$ &, $539^{1}$ & $\begin{array}{l}\text { Retain the null } \\
\text { hypothesis. }\end{array}$ \\
\hline
\end{tabular}

Asymptotic significances are displayed. The significance level is ,05

${ }^{1}$ Exact significance is displayed for this test

Pre_Test

General Education Teachers Special Education Teachers

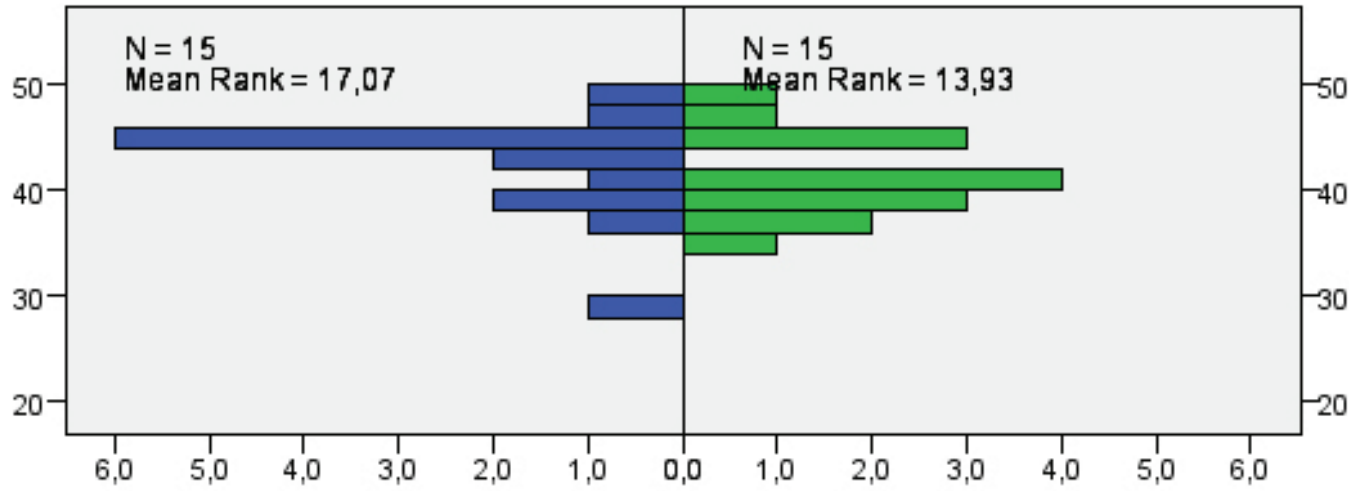

Post Test

General Education Teachers Special Education Teachers

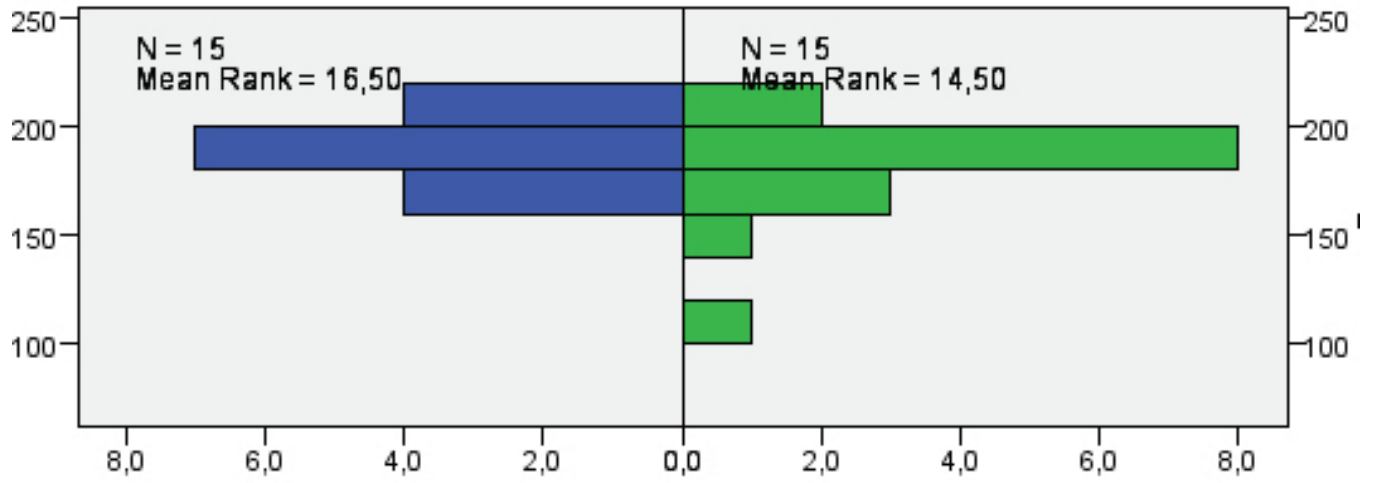

Figure 2: Model viewer for non-parametric, independent samples, Mann-Whitney $U$ for "general and special teachers" pre and post test. 
Finally, the TSES 24-item was evaluated in both pre and post phases, the Cronbach's alpha was 0,780 in the pre training phase and 0,939 in the post training phase.

The open-ended questionnaire was analyzed qualitatively and the following was found: as far as the stage of teaching design is concerned, half of the participants reported that they do not initially design their teaching schedule, while, after the program's completion, almost all of the participants reported that they prepared a teaching schedule. Concerning the use of alternative teaching methods, before their participation in the program, there was a significant number of the participants who used alternative methods, which increased after the implementation of the program. Regarding cooperation, it seems that initially all special educators used to cooperate with their general education colleagues, while less general educators initially cooperated with special educators. After the completion of the program all the general educators reported that they had started cooperating with special educators.

There was a relative differentiation traced in educators' attitudes concerning students' evaluation. When asked how they used the material that resulted from the evaluation procedure, they responded that they used initial evaluation data for choosing teaching objectives, and final evaluation data for the final evaluation stage in order to get feedback concerning their teaching aims or for reviewing their intervention.

Concerning the strategies that educators used with different target-groups and special needs categories, it has been proven that educators have significantly enhanced their strategy repertoires. When they were asked whether the students of their school were sensitized towards issues of special education and inclusion of children with learning disabilities, few of teachers initially answered positively, whereas, after the training program, the percentage of the positive answers increased significantly. Finally, they were asked if they thought that they could further contribute to this sensitization both before and after their in-service training. The vast majority of them answered positively after the completion of the program. Finally, almost every educator reported the use of a great variety of modes, techniques, methods etc. employed for the purpose of the program.

\section{Discussion}

The present study has presented an in-service training program for general and special teachers, following the theoretical principles of the effective, inclusive and collaborative school, thus this program aimed to improve the basic instructional skills of teachers in the interest of any student with various learning problems. The methodology of the program was based on the Bobb and Earley cycle of vocational training (2007). The research findings show that in similar training seminars and programs the participation of educators is mostly correlated with their ambition for improvement of their professional status, and secondarily with the need for improving their instructional skills and teaching practices (OECD, 2005).

The program was evaluated by the participants towards the quality of its design and implementation, also, the participants reported the influence of the program on their teaching skills. Moreover, the potential impact of the program on the self-efficacy of the participants was estimated. Additionally, the ongoing procedure of training was continuously monitored by the researchers and participants, and their feedback was taken into account to make changes for improving the quality of the program in accordance with Bobb and Earley, (2007). The final estimation of the quality of the program by the participants was positive, possibly because of the continuous monitoring and the proposed changes, which contributed to shaping this highly positive estimation, since those program reviews and adaptations had managed to meet their needs.

On the other hand, the findings showed that the program influenced positively the participants' skills as regards lesson planning, teaching methods, cooperation between general and special teachers for improving the process of students' assessment, planning and implementing interventions for learning disabled students. Particularly, the participants stated that their 
PROBLEMS

OF EDUCATION

IN THE $21^{\text {st }}$ CENTURY

Volume 64, 2015

104

practices concerning students' assessment and use of assessment data as a basis for the design of lesson plans and interventions were positively influenced by the program, in consistency with Horrocks', (2010) findings. Also, the findings showed that the embedding of the effective teaching strategies in daily teaching routine was increased, inclusive procedures were reinforced, effective instructional strategies were proposed, and behavior management strategies were indicated.

Additionally, the findings showed that the impact of the program on the teachers' selfefficacy was notable concerning all the self-efficacy elements. The pre and post training difference in the self-efficacy data were statistically significant. That means, that the improvement of self-efficacy of the participants was remarkable and as it is also supported by the literature high self-efficacy is generally linked to strong motivation for teaching (Fives, 2003), and successful classroom management (Raudenbush, Rowan \& Cheong, 1992). Moreover, many researchers have noted that the implications of the significant increase of educators' sense of self-efficacy could influence their effort to apply their new skills in the teaching practice. Consequently, teachers' training may indirectly have an important impact on the real life of the school (Tschannen-Moran \& Hoy, 2001; Woolfolk et al., 2008; Oorsouw et al, 2009; Horrocks, 2010).

However, these findings were based on self-reported data regarding participants' attitudes and perceptions that are very often more positive than their instruction itself as it could be assessed by independent observers (Tzivinikou \& Papoutsaki, 2014). But, in any case, the research evidence shows that self-reported data from adults in a training procedure can be accepted as valid, as emerges from Knowles', (1984) definition of adult self-concept "As a person matures his self-concept moves from one of being a dependent personality toward one of being a self-directed human being" ( pp. 12).

The present in-service training for professional development of general and special educators has been organized and implemented in a research-based way and with respect to adult education principles (Knowles, 1984; Kokkos, 1999), in order to ensure their high quality and consequently, the satisfaction of the participants' learning needs, elements which influence the development of the sense of effectiveness among trainees in consistence with Darling-Hammond et al., (2012) and Duffin, et al., (2012) suggestions. That preparation and implementation had added value to the training, which probably contributed to the acceptance of the participants as highly effective and influential in relation to their teaching skills.

Another explanation of the effectiveness of the training program was its detailed and careful preparation and the fact that during its design phase, educators' cognitive prerequisites were taken into account, and the relevant learning readiness of the participants was defined, both in the context of different groups (general and special educators) and individually for each participant. Their involvement into the teaching process and the interactive connection of theory and practice added value to the effectiveness of the program, a fact that comes into agreement with the view of Papanaoum, (2008). Additionally, shared and intense interest expressed by the participants, a priori acceptance of one another as equivalent colleagues in the context of general or inclusion classroom, their intention to go beyond the standard basis and implement new knowledge, were a very important advantage.

The cooperation between the general and special educators was the most important feature of the training program, mainly from the perspective of the general teachers, because they had no previous experience in collaborating with other educational stuff in their schools, while on the contrary, special educators had significant experience in collaboration practices. Thus, at the end of the training program, all the participants noted that they were interested in collaborating with their colleagues and they started taking initiatives for cooperation more often and more effectively. This finding was very important, because cooperation is one of the crucial elements of effective teaching, according to the arguments of Sledge and Pazey, (2013).

Finally, an indirect impact of the training program, though not systematically investigated, but emerging as an empirical estimation of the researchers, was the fact that in the schools where the trainees-educators were appointed and where the joint educational interventions took 
place, the interest of the teaching personnel reignited fruitful discussions, the dialogue and communication among the teachers were reinforced, competitiveness was limited, educational initiatives were developed, new knowledge was taken into account and used effectively, and finally, a positive environment was cultivated for the emergence of new knowledge and data. Therefore, the schools of the participants had developed and enriched the learning environments by improving learning opportunities for both students and educators, as Rosenholtz, (1991) has stated.

\section{Limitations and Implications for the Field of Education}

There were some major and minor limitations. First of all, the sample size was limited, although almost all of the special educators of the specific area participated in the study, due to a small number of special educators in general.

On the other hand, the most important research limitation is the difficulty for the training program to be institutionalized and implemented on a regular basis and with a specific frequency so as to address the learning needs of a greater number of educators. Consequently, as it occurs in the context of other successful training programs, they remain non-recurring -and concern only a limited number of educators- and without a chance of continuity if they are not institutionally supported.

In general, despite the general consensus regarding the significance of educators' training for their professional development and the continuous development and improvement of the educational system, the necessary financial support is not available and relevant policies to support this institution are absent.

Finally, it is intended to further investigate the impact of this training program on educational praxis in the near future. Specifically, after the completion of one academic year, during the current academic year, we intend to investigate the persistence and generalization of the training's impact so as to detect whether the positive influence recorded initially, will still be maintained positive.

\section{Conclusions}

Overall, the impact of an in-service training that aimed at improving the teaching efficacy of general and special teachers working together in the heterogeneous classes was estimated in the present study. It is widely accepted that self-efficacy affects teaching practices and teacher effectiveness, as well as teachers with high self-efficacy are devoted to teaching and tend to exhibit great levels of enthusiasm, therefore, develop better teaching skills. The present study evaluated self-efficacy using the well-known checklist from literature, TSES (TschannenMoran \& Woolfolk Hoy, 2001) and an open-ended questionnaire so as to record the teachers' perceptions about the impact of the training program on their teaching skills. The quantitative and qualitative analysis yielded that the training program has positively influenced the teachers' self-efficacy, as not only the differences on pre and post training self-efficacy measures were statistically significant, but also the teachers' perceptions about their teaching skills improvement were positive. Specifically, the findings showed that the program influenced positively the participants' skills regarding lesson planning, teaching methods, cooperation between general and special teachers for improving the process of students' assessment, planning and implementing interventions for learning disabled students, and the factor "general or special teacher" was not influenced by the findings. Thus, the impact of the training program on the general and special teachers' self-efficacy was considered as quite positive, however, with some important limitations concerning the generalization of the results. 
Sotiria TZIVINIKOU. The impact of an in-service training program on the self-efficacy of special and general education teachers

PROBLEMS

OF EDUCATION

IN THE $21^{\text {st }}$ CENTURY

Volume 64, 2015

106

\section{Acknowledgements}

The author gratefully acknowledges Alexandra Fountoukidou, Ph.D. student, for Englishlanguage editing.

\section{References}

Bobb, S., \& Earley, P. (2007). Leading and managing continuing professional development. $2^{\text {nd }}$ ed. London: SAGE Publications.

Caprara, G. V. Barbaranelli, C., Steca, P., Malone, S. P. (2006). Teachers' self-efficacy beliefs as determinants of job satisfaction and students' academic achievement: A study at the school level. Journal of School Psychology 44, 473-490.

Cohen, L., Manion, L., Morrison, K. (2011). Research methods in education. New York: Routledge.

Darling-Hammond, L., Amrein-Beardsley, A., Haertel, E., \& Rothstein, J. (2012). Evaluating teacher evaluation. Phi Delta Kappan, 93 (6), 8-15.

Duffin, C. L., French, F. B., Patrick, H. (2012). The teachers' sense of efficacy scale: Confirming the factor structure with beginning pre-service teachers. Teaching and Teacher Education, 28, 827-834.

Henson, R. K. (2001). Teacher self-efficacy: Substantive implications and measurement dilemmas. Invited keynote address given at the annual meeting of the Educational Research Exchange, January 26, 2001, Texas A\&M University, College Station, Texas. Retrieved 6/5/2015 from http://www. uky.edu/ eushe2/Pajares/EREkeynote.PDF

Horrocks, L. E. (2010). The effects of in-service teacher training on correct implementation of assessment and instructional procedures for teachers of individuals with profound multiple disabilities. Ph.D. dissertation, Utah State University. Retrieved from http://digitalcommons.usu.edu/cgi/viewcontent.cgi?article $=1583 \&$ context $=$ etd.

Jarvis, P. (1987). 'Malcolm Knowles'. In P. Jarvis (ed.) Twentieth century thinkers in adult education. London: Croom Helm.

Knight, J. (2007.) Instructional coaching: A partnership approach to improving instruction. Thousand Oaks, CA: Corwin Press.

Knight, J. (2009). The big four: A simple \& powerful framework to dramatically improve instruction. Strategram: University of Kansas, Center for research on learning, vol. 21 (4), 1-5.

Knowles, S. M. (1984). Andragogy in action: Applying modern principles of Adult learning. San Francisco: Jossey-Bass Publishers.

Kyriakides, L., Creemers, B. P. M., \& Antoniou, P. (2009). Teacher behaviour and student outcomes: Suggestions for research on teacher training and professional development. Teaching and Teacher Education, 25 (1), 12-23.

McGuiness, M. (2006). Practical applications of personality theory in career development and workplace coaching. Proceedings of the Eighth Biennial National Conference of the Australian Association for Psychological Type, Brisbane [CD]. Retrieved from http:/www.aapt.org.au/.

Oorsouw, W. M., Embregts, P. J., Bosman, A. M., \& Bosman, A. M. (2013). Quantitative and qualitative processes of change during staff-coaching sessions: An exploratory study. Research in Developmental Disabilities, 34, 1456-1467.

Oorsouw, W. M., Embregts, P. J., Bosman, A. M., \& Jahoda, A. (2009). Training staff serving clients with intellectual disabilities: A meta-analysis of aspects determining effectiveness. Research in Developmental Disabilities, 30, 503-511.

Pajares, F. (1996). Self-Efficacy beliefs in academic setting. Review of Educational Research, 66 (4), 543-578.

Raudenbush, S. W., Rowan, B., \& Cheong, Y. F. (1992). Contextual effects on the self perceived efficacy of high school teachers. Sociology of Education, 65, 150-167.

Rossett, A., Douglis, F., \& Frazee, R. (2003). Strategies for building blended learning. Retrieved from http://www.learningcircuits.org/2003/jul2003/rossett.

Sledge, A., Pazey, L. B. (2013). Measuring teacher effectiveness through meaningful evaluation: Can reform models apply to general education and special education teachers? Journal of Teacher Education Division of the Council for Exceptional Children, Retrieved from http://tes.sagepub. com/content/early/2013/06/20/0888406413489839.

Tschannen-Moran, M., \& Hoy, A. W. (2001). Teacher efficacy: Capturing an elusive construct. Teaching and Teacher Education, 17 (7), 783 - 805. 
Tzivinikou, S., \& Papoutsaki, K. (2014). A research for teaching methods, strategies and best practices at resource rooms. Paper presented at 24th European Early Childhood Education Research Association (EECERA) Conference, Crete, Greece.

Tzivinikou, S. (2015, in press). Building effective co-teaching in inclusive settings: considerations from 15 case studies. Problems of Education in the 21st Century.

Woolfolk, A., Hughes, M., Walkup, V. (2008). Psychology in Education. London: Pearson.

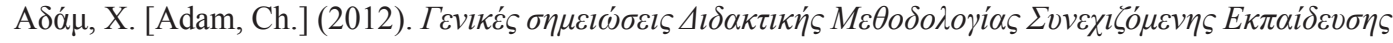
[General notes in didactic methodology of continuing education]. Retrieved from http://charalampos.gr/2012/didaktiki-methodologia/.)

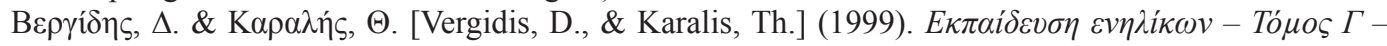

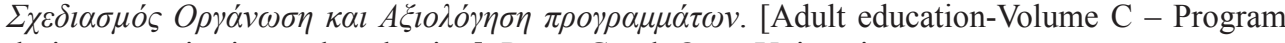
design, organisation and evaluation]. Patra: Greek Open University.

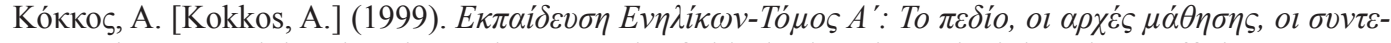
$\lambda \varepsilon \sigma \tau \dot{\varepsilon} \varsigma$. [Adult Education-Volume A: The field, the learning principles, the coefficients]. Patra: Greek Open University.

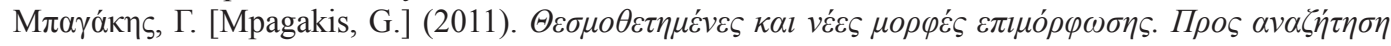

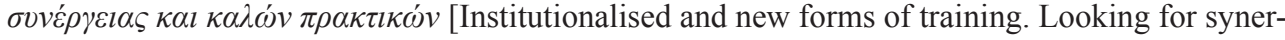
gies and best practices] OEPEK, Operational Program "Education and Lifelong Learning". Retrieved from http://www.oepek.gr/pdfs/Vivlio_kales_praktikes.pdf.

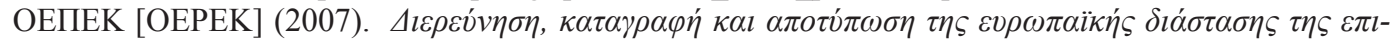

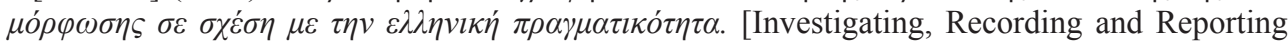

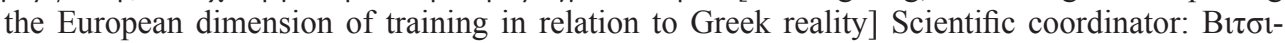

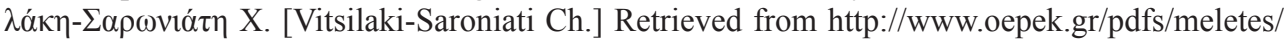
oepek_meleth_05.pdf $\pi \rho 0 \sigma \pi \varepsilon \lambda \alpha \dot{\sigma} \sigma \eta \kappa \varepsilon \sigma \tau 1 \varsigma 3-8-2012$.

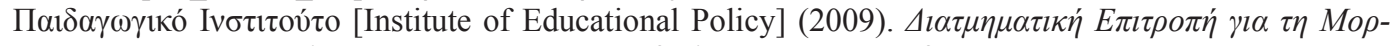

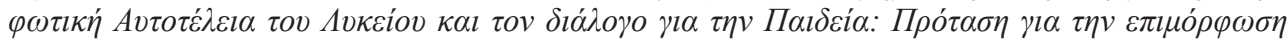
$\tau \omega v \varepsilon \kappa \pi \alpha \iota \delta \varepsilon v \imath \kappa \omega ́ v$. [Inter-institutional Committee for the Educational Independency of Lyceum and the Dialogue for Education: Proposal for training educators]. Retrieved from http://www.pischools.gr/paideia_dialogos/prot_epimorf.pdf.

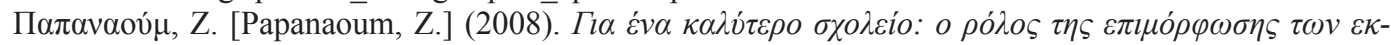
$\pi \alpha \imath \delta \varepsilon v \tau \imath \kappa \omega ́ v$ [For a better school: the role of training educators]. Institute of Educational Policy. Retrieved from http://repository.edulll.gr/105.

Advised by Laima Railienè, Šiauliai University, Lithuania

Received: February 03, 2015

Accepted: April 23, 2015

\begin{tabular}{l} 
OF EDUCATION \\
IN THE 21 $1^{\text {st }}$ CENTURY \\
Volume 64, 2015 \\
\hline 107
\end{tabular} 